\title{
Efficiency of Amino Alcohols as Corrosion Inhibitors in Reinforced Concrete
}

\author{
Ioannis Vyrides ${ }^{1}$, Eleni Rakanta ${ }^{2}$, Theodosia Zafeiropoulou ${ }^{2}$, George Batis ${ }^{2}$ \\ ${ }^{1}$ Department of Chemical Engineering and Chemical Technology, Imperial College, London, UK \\ ${ }^{2}$ School of Chemical Engineering, National Technical University of Athens, Athens, Greece \\ Email: ioannis.vyrides@imperial.ac.uk, erakanta@central.ntua.gr,dia_zaf@mail.ntua.gr, batis@chemeng.ntua.gr
}

Received May 1, 2013; revised June 2, 2013; accepted June 10, 2013

Copyright (C) 2013 Ioannis Vyrides et al. This is an open access article distributed under the Creative Commons Attribution License, which permits unrestricted use, distribution, and reproduction in any medium, provided the original work is properly cited.

\begin{abstract}
The objective of this paper is to investigate the behaviour of amino alcohol corrosion inhibitors when they are used in reinforced cement mortars either as admixtures in the cement paste or as coating applications on the surface of the rebars. The reinforced cement mortars were exposed to both partial and full immersion in $3.5 \mathrm{wt} \% \mathrm{NaCl}$ solution. Electrochemical measurements such as half-cell potential and linear polarization technique, as well as weight loss of the embedded rebars were performed in order to obtain information on the corrosion behaviour of the reinforcing steel in cement mortar. Results demonstrate that the amino alcohol corrosion inhibitors offer protection against rebar corrosion in cement mortars.
\end{abstract}

Keywords: Steel Corrosion; Concrete Durability; Amino Alcohols; Corrosion Inhibitors; Cement Mortars

\section{Introduction}

Under most conditions concrete provides a reliable protection against corrosion of reinforcing steel, however corrosion remains the most common cause of deterioration of reinforced concrete. In order for corrosion to occur, the presence of an electrolyte such as the aqueous phase in concrete is required. The final result of the corrosion process is the formation of a thick layer of rust which exerts sufficient tensile forces within the concrete to cause cracking of the concrete cover [1]. In an alkaline solution, such as the calcium hydroxide solution in wet cement, a protective oxide film is formed which covers the steel thus passivates it. Corrosion occurs when this protective film is impaired and oxygen is present [2]. Oxygen has the most detrimental effect; chloride is only the catalyst of the corrosion process. Oxygen binds the electrons originally associated with the iron atoms and it is the abstraction of these electrons which allows some iron atoms to dissolve as ferrous ions and then to preipitate as ferric oxides [3]. Without oxygen steel rebar will not corrode in alkaline water even with chloride present [4]. Moreover, the stability of the film depends on the maintenance of a certain minimum $\mathrm{pH}$ value above which access of oxygen will not cause corrosion. However, if the access of carbon dioxide reduces the $\mathrm{pH}$ to a value 10 or lower the film is impaired, the natural passivity of concrete is thus reduced and under such conditions any access of oxygen will cause corrosion [5]. The presence of chloride ions stimulates corrosion by raising the $\mathrm{pH}$ required to stabilize the passive film to a value which may exceed that of a saturated calcium hydroxide solution. The intrusion of chloride ions depends on the porosity and permeability of the concrete material [1]. As the reinforcing steel corrodes, the ferric oxides occupy a volume three to four times greater than the initial reinforcing steel resulting in bursting stresses that crack and spall the concrete cover.

Corrosion inhibitors have been used successfully in steel pipelines, tanks, etc., for many decades. Their use as admixtures to concrete, however, is more recent and more limited. This reluctance is due to the fact that they could not be changed if found to be ineffective, replenished if found to be consumed, or removed if found to have deleterious effects [6]. The flexibility of corrosion inhibitors with regard to dosage and their compatibility with all aspects of construction and operation of structures makes them useful for protection against corrosion. Any inhibitor should have good solubility characteristics and rapidly saturate the corroding surface. Also the physical and durability properties of concrete should not be adversely affected [7].

Amino alcohol corrosion inhibitors control corrosion 
by attacking the cathodic activity, blocking sites where oxygen picks up electrons and is reduced to hydroxyl ion. Also inhibition of corrosion occurs through a mechanism where by amino alcohols displaces chloride ion and forms a durable passivating film. In this view, although the amino alcohols adsorb on non-corroding sites which may seem more cathodic than anodic, they can just as easily be said to adsorb on potentially anodic sites as well [3]. Ormellese et al. [8] suggest that organic corrosion inhibitors reduce the ingress of chloride by filling concrete pores and blocking the porosity of concrete by the formation of complex compounds. Thus, the value of chlorides reaching to the steel surface is significantly less so the corrosion is inhibited. Several studies of the corrosion inhibition effect of amino alcohols for steel report their performance as a function of concentration and $\mathrm{pH}$ in saline solutions [9-11]. In particular, the colorimetric and electrochemical study of 2-ethylaminoethanol observed that the molecules do not provide a protective film in neutral media, but rather enhance the corrosion rate. At $\mathrm{pH}>10.3$ a protective layer of metalhydroxide is formed, which, however, is not completely insoluble. This hydroxide film can be stabilized by adsorption of 2-ethylaminoethanol on the hydroxylated surface and presumably by chelation of the ferrous ion $[12,13]$.

An amino alcohol corrosion inhibitors can be mixed within the fresh concrete (admixture inhibitor), or can be applied on the surface of existing concrete structures. In this study the contribution of both types' admixtured and spraying applied corrosion inhibitors was investigated. Moreover, when the corrosion action was under progress, the addition of spaying amino alcohol inhibitor was tested. Furthermore, attention was given to the condition that the specimens were exposed, partially immersed in a $3.5 \mathrm{wt} \% \mathrm{NaCl}$ solution and in a saturated $3.5 \mathrm{wt} \% \mathrm{NaCl}$ solution.

\section{Experimental}

\subsection{Materials}

To achieve the objectives of this investigation cylindrical reinforced cement mortar specimen were constructed. The test specimens were prepared with cement, sand and water in ratio 1:3:0.6. The cement type used was Greek Portland cement and its chemical analysis is shown in Table 1 and the water was tap from Athens water supply network appropriate for preparing specimens according to ELOT 452 [14]. Cylindrical steel rebars of type B500C with dimensions of $12 \mathrm{~mm}$ in diameter and 10 $\mathrm{mm}$ high were used for the reinforced test specimens. The rebars meet Greek specifications of Hellenic Organization for Standardization, ELOT 1421-3 [15].

Fabrication of the steel for the test specimens simply involved cutting to the consistent length of $100 \mathrm{~mm}$. The test specimens considered for the present study were cylindrical $100 \mathrm{~mm}$ in height and $40 \mathrm{~mm}$ in diameter. Each contained one steel rebar in the position shown in Figure 1. The cement mortar constituents were mixed in a mortar mixer for approximately 5 minutes till a uniform consistency was achieved. The molds were filled with mortar and vibrated for consolidation using a vibrating table. Copper wire cables were connected to the steel bar for electrochemical measurements. Prior to the preparation, the steel surface was cleaned according to the ISO/DIS 8407.3 Standard [16]. In particular the surface of the steel bars was washed with water and then immersed in strong solution of $\mathrm{HCl}$ with organic corrosion inhibitor for $15 \mathrm{~min}$, washed with water and finally washed thoroughly with distilled water to eliminate traces of the corrosion inhibitor and chloride ions. Following that, the surface was cleaned with alcohol and acetone and finally weighed to accuracy of $0.1 \mathrm{mg}$. Thereafter, the bars were placed in cylindrical moulds where the mortar was cast and stored at ambient conditions in the laboratory for 24 hours. After being demolded, the specimens were placed in water in curing room $\left(\mathrm{RH}>98 \%, \mathrm{~T}=20^{\circ} \mathrm{C} \pm 1.5^{\circ} \mathrm{C}\right)$ for 24 hours and then kept for an additional 7 days at ambient temperature in a laboratory environment to stabilize internal humidity, followed by insulation with epoxy resin of the region shown in Figure 1. The experimental duration of this study was 200 days.

For the purpose of this work 4 series of specimens were partially immersed in a $3.5 \mathrm{wt} \% \mathrm{NaCl}$ solution and 2 series remained fully immersed in a $3.5 \mathrm{wt} \% \mathrm{NaCl}$ solution. The addition of the corrosion inhibitor was achieved according to the instruction given by the manufacturer. The analytical series tested in this work are presented in Table 2.

In Table 2 test series that were partially immersed in

Table 1. Chemical analysis of OPC.

\begin{tabular}{lllllllllll}
\hline \multicolumn{8}{c}{ Oxide composition of cement (\% by weight of cement) } \\
\hline $\mathrm{SiO}_{2}$ & $\mathrm{Al}_{2} \mathrm{O}_{3}$ & $\mathrm{Fe}_{2} \mathrm{O}_{3}$ & $\mathrm{CaO}$ & $\mathrm{MgO}$ & $\mathrm{K}_{2} \mathrm{O}$ & $\mathrm{Na}_{2} \mathrm{O}$ & $\mathrm{SO}_{3}$ & LOI & $\mathrm{CaO}_{\mathrm{f}}$ \\
\hline 20.67 & 4.99 & 3.18 & 63.60 & 2.73 & 0.37 & 0.29 & 2.414 & 2.52 & 2.41 \\
\hline
\end{tabular}

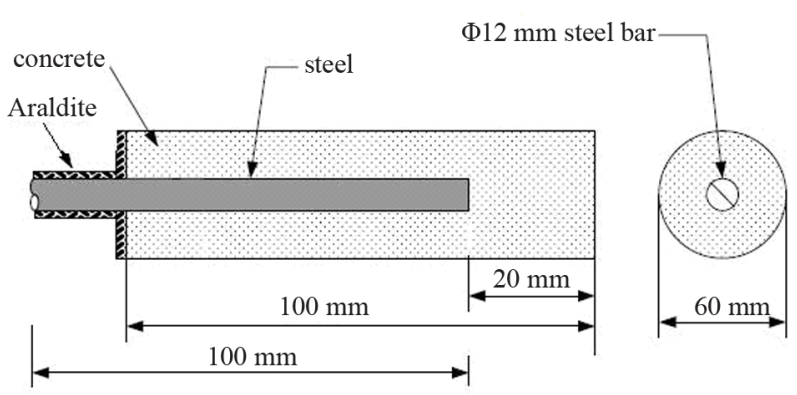

Figure 1. Schematic representation of a reinforced mortar specimen. 
Table 2. Test series used in the present study.

\begin{tabular}{|c|c|c|}
\hline $\begin{array}{l}\text { Code names } \\
\text { of the series }\end{array}$ & Environment & Characteristics \\
\hline RSA & Partially immersed & Control specimens \\
\hline DSA & Partially immersed & $\begin{array}{l}\text { Inhibitor as admixture } \\
\quad(4 \mathrm{wt} \% \text { cement })\end{array}$ \\
\hline DSA14 & Partially immersed & $\begin{array}{l}\text { Inhibitor sprayed after } 14 \text { days } \\
\text { from the day of manufacture }\end{array}$ \\
\hline DSA3M & Partially immersed & $\begin{array}{c}\text { Inhibitor sprayed after } 3 \text { months } \\
\text { of exposure in the corrosive } \\
\text { environment }\end{array}$ \\
\hline RSB & Fully immersed & Control specimens \\
\hline DSB & Fully immersed & $\begin{array}{l}\text { Inhibitor as admixture } \\
\quad(4 \mathrm{wt} \% \text { cement })\end{array}$ \\
\hline
\end{tabular}

the solution are indicated with " $A$ " whereas full immersion is characterized by using the letter " $B$ " in the code name of the series. Furthermore, "RS" stands for reference specimens and "DS" for data specimens where the inhibitor is either sprayed or as an admixture. Finally, the numbers on the code names show the time interval before the corrosion inhibitor was sprayed on the surface of the specimens.

The corrosion inhibitor used in this study was based on partially neutralized amino alcohols which is an adsorption inhibitor. Specifically, N-N-diethylaminoethanol is absorbed onto the steel surface forming organic films which protect both the anodic and cathodic sections of the rebar [17]. Besides, the transportation of surface applying amino alcohols inhibitor into concrete depends on the concrete quality, the porosity and the humidity [18, 19].

\subsection{Methods}

The following methods were employed in this study for the evaluation of the protective action of coatings against corrosion:

a) Half-Cell Potential Measurements versus Time:

During the exposure of the specimens in the corrosive environment the half-cell potential of steel rebars was periodically measured versus a saturated calomel electrode (SCE) and a high impedance voltmeter. According to ASTM C876 Standard [20] corrosion potentials $\left(E_{c o r r}\right)$ more negative than $-350 \mathrm{mV}$, with respect to $\mathrm{SCE}$, indicate greater than $90 \%$ probability of active reinforcement corrosion. Values less negative than $-200 \mathrm{mV} \mathrm{SCE}$ indicate a probability of corrosion below 5\%, while those falling between -200 and $-350 \mathrm{mV} \mathrm{SCE}$ indicate uncertainty of corrosion.

\section{b) Linear Polarization Technique (LPR):}

The corrosion of reinforced concrete is an electrochemical process. For this reason it is possible to obtain the information on the state of corrosion with the application of external electrical stimulation and measurement of the subsequent electrical response. Hence, the linear polarization resistance method was used to measure corrosion rates over various time periods Although the corrosion of steel in concrete is an electrochemical process and does not obey to Ohm's law it has been shown that Ohms's law will be approximately true if polarization applied to the steel does not exceed $\pm 20 \mathrm{mV}$. Thus the resulting current is linearly plotted versus potential. The test setup for the linear polarization resistance techniques (LPR) included a EG\&G Model 263 Potensiostat/Galvanostat. Additionally the computer program Softcorr III developed by EG\&G Princeton Research was used for applying the potential scan, analyzing the parameters of $i_{\text {corr }}$ and $R_{p}$. The linear polarization resistance of steel reinforcement was evaluated at a scan rate of $0.15 \mathrm{mV} / \mathrm{s}$. The corrosion current density was measured using the DC linear polarization resistance method. The resistance to polarization $R_{p}\left(\Omega \cdot \mathrm{cm}^{2}\right)$ was determined by conducting a linear polarization scan in the range of $20 \mathrm{mV}$ of the open circuit potential and the corrosion current density $i_{\text {corr }}\left[\mu \mathrm{A} / \mathrm{cm}^{2}\right]$ was then calculated using the Stern-Geary equation:

$$
i_{\text {corr }}=\frac{B}{R_{p} \cdot A}
$$

where $B$ is a constant based on the anodic and cathodic Tafel constants where a value of $26 \mathrm{mV}$ has been adopted for active corroding steel bars and $52 \mathrm{mV}$ for passive conditions and $A\left(\mathrm{~cm}^{2}\right)$ is the exposed area of the rebar.

This method has been considered to be a relatively simple and reliable technique to assess the rate of reinforcement corrosion in cement mortars. The corrosion level is considered negligible when $i_{\text {corr }}$ is less than 0.1 $\mu \mathrm{A} / \mathrm{cm}^{2}$, it is considered low in the range between 0.1 and 0.5 , moderate from 0.5 to 1 and high for values higher than $1 \mu \mathrm{A} / \mathrm{cm}^{2}$ [21].

c) Weight Loss Measurements of Steel Rebars:

The corrosion rate of reinforcing steel was determined by measuring the mass loss of the steel bars in different times. The steel bars were cleaned from any corrosion products according to the ISO/DIS 8407.3 Standard [16] and were weighted to accuracy of $0.1 \mathrm{mg}$. The average mass loss was calculated from the difference between the initial and the final weight of each steel bar.

\section{Results and Discussion}

\subsection{Half-Cell Potential Measurements}

Half-cell potentials of the specimens that were partially immersed in $3.5 \mathrm{wt} \% \mathrm{NaCl}$ solution for 200 days are shown in Figure 2. In the cement mortar specimens without corrosion inhibitor (RSA) the corrosion poten- 


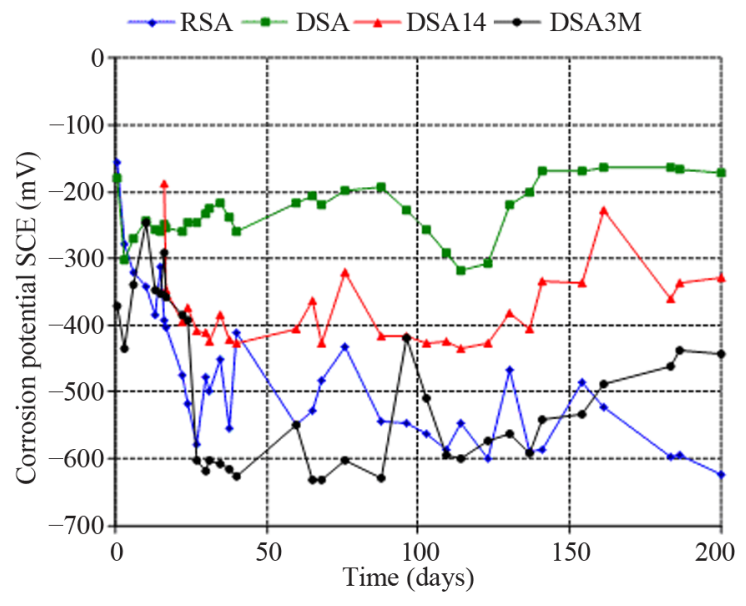

Figure 2. Half-cell potential measurements versus time in cement mortar specimens partially immersed in $3.5 \mathrm{wt} \%$ NaCl solution.

tials were more negative than $-300 \mathrm{mV}$ SCE right from the initial stages of exposure and $-620 \mathrm{mV} \mathrm{SCE}$ after 200 days of exposure. The half-cell potentials of specimens which an amino alcohol inhibitor was used as an admixture (DSA) show an increase of the potential values in the anodic direction during the first 90 days, attaining values around $-195 \mathrm{mV}$. After that the potential slightly decays to values around $-270 \mathrm{mV}$ and finally reaches steady values around $-170 \mathrm{mV}$ indicating the passivity of reinforcing steel even after 200 days of exposure. The spraying applied amino alcohol corrosion inhibitor (DSA14) during the first 125 days of exposure remains practically constant with the time at values around $-420 \mathrm{mV}$. However, after the first 125 days the half-cell potentials values are higher than the initial ones by $-100 \mathrm{mV}$ and remain in that value $(-328 \mathrm{mV})$ until the end of the experiment. According to ASTM this is an indication of uncertainty of corrosion [20]. In the cement mortar specimens (DSA3M) that an amino alcohol inhibitor was applying by spraying at specimens' surface after 3 months the potential sharply decays to values around $-620 \mathrm{mV}$. This decay of potential suggests loss of passivation. After the surface applying inhibitors at the $90^{\text {th }}$ day there is a gradual increase in the half-cell potential values followed by stabilization at around $-450 \mathrm{mV}$.

Despite the fact that these values are an indication of $90 \%$ probability of active reinforcement corrosion [20], the addition of the amino alcohol spaying inhibitor shows its effect on the cement mortar samples in the first days of the applying by significantly increase of the half-cell potential. The half-cell potentials results show that the effect of the inhibitor addition on the corrosion rate of reinforcing steel is dependent on the method of application. Thus, when the inhibitor is sprayed on specimens the corrosion inhibition is delayed comparatively to the situation in which the inhibitor is added into the cement mortar mixture.

Figure 3 depicts the half-cell potentials of control speci-mens and specimens that an amino alcohol inhibitor was used as an admixture. Both types were fully immersed in $3.5 \%$ wt. $\mathrm{NaCl}$ solution for 200 days. There is a tendency for the decreasing of potential from values range of -100 : $-200 \mathrm{mV}$ to values of $-600 \mathrm{mV}$ for the both types of specimens.

The decrease in the specimens with amino alcohol corrosion inhibitor was more gradual compared to the rapid decrease of the specimens without corrosion inhibitor during the period $0-150$ days. However, this is a very slightly indication of the better performance of the corrosion inhibitor because these values are below -350 $\mathrm{mV}$. The amino alcohol corrosion inhibitor may displace chloride ion to create a passive film so the anodic reaction of iron are lower compared to the specimens without inhibitors during this period (0 - 150 days) [20]. Despite this dramatic decrease in the values of the half-cell potential for the both specimens probably the generation of ferrous oxide did not take place due to the absence of oxygen (fully immersed in $3.5 \% \mathrm{wt}$. $\mathrm{NaCl}$ solution). As a consequence, without oxygen caused by water saturation, iron will dissolve in excess of electron but will remain stable in solution as there is no compensating cathodic reaction so the potential is very negative. This shows the weakness of potential measurements in an environment without oxygen [22].

\subsection{Linear Polarization Measurements}

In previous works electrochemical experiments pointed out that amino alcohol corrosion inhibitor increased the corrosion resistance of steel samples immersed in solution simulating the concrete pore solution contaminated with chloride [23-30]. In fact, X-ray photoelectron spectroscopy analysis revealed that the inhibitors form a film containing nitrogen species, which seem to complex the

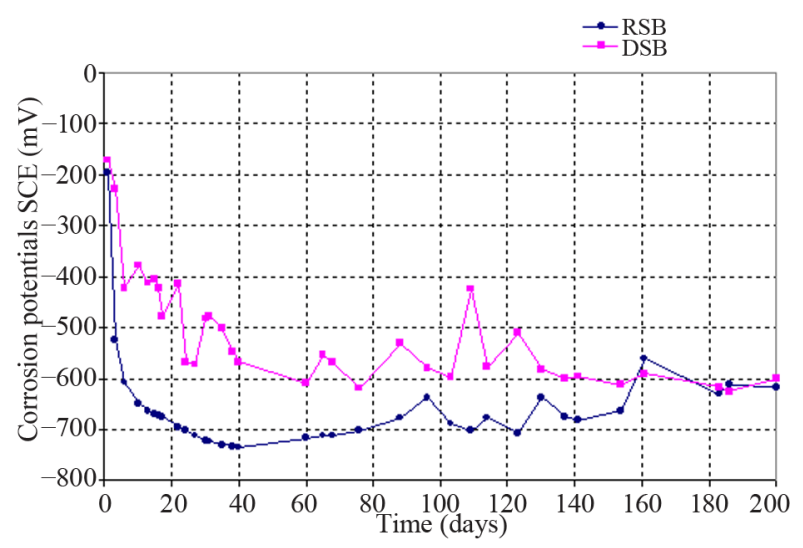

Figure 3. Half-cell potential measurements versus time in cement mortar specimens fully immersed in $3.5 \mathrm{wt} \% \mathrm{NaCl}$ solution. 
chloride ions [23]. Previous different electrochemical measurements also showed that the amino alcohol inhibitors can reduce the corrosion rate even when steel is under corrosion attack [23-25]. Considering these results, the present work studies the ability of amino alcohol inhibitor to resist corrosion by measuring the corrosion current density in $3.5 \mathrm{wt} \% \mathrm{NaCl}$ solution.

Figure 4 depicts the corrosion current density $i_{\text {corr }}$ on rebars of the cement mortar specimens that were partially immersed in $3.5 \mathrm{wt} \% \mathrm{NaCl}$ solution for 200 days. As it is shown $i_{\text {corr }}$ values of the rebars without inhibitor increases with the exposure time from $2.2 \mu \mathrm{A} / \mathrm{cm}^{2}$ to 4.5 $\mu \mathrm{A} / \mathrm{cm}^{2}$, values typical of high corrosion levels. It is also depicted that the usage of the corrosion inhibitor as an admixture (DSA) resulted in lower $i_{\text {corr }}$ values $(0.45$ $\mu \mathrm{A} / \mathrm{cm}^{2}$ ) which are indicative of low corrosion activity. For the specimens that the corrosion inhibitor was sprayed on the surface (DSA14), moderate corrosion values were achieved $\left(0.78 \mu \mathrm{A} / \mathrm{cm}^{2}\right)$.

These results show that the performance of the admixture amino alcohol inhibitor was better compared to the sprayed corrosion inhibitor. The admixture corrosion inhibitor occurs homogeneously inside the cement paste and as a result it is easier to generate the passive film to the surface of steel. Moreover, it is more effective in reducing the porosity of the cement paste by forming complex compounds with chlorides [8]. In contrast, the behavior of the sprayed corrosion inhibitor depends on the values of the diffusion coefficients of the inhibitor and the diffusion coefficient of chlorides.

The behavior of the sample that was kept 3 months in the corrosive environment with no inhibitor (DSA3M) in order to develop stronger corrosion activity and was afterwards sprayed with the inhibitor must be noted.

During the first period $i_{\text {corr }}$ values slightly decrease from $3.2 \mu \mathrm{A} / \mathrm{cm}^{2}$ to $3.1 \mu \mathrm{A} / \mathrm{cm}^{2}$. After the inhibitor application in the surface of the specimen $i_{\text {corr }}$ decreases to $0.86 \mu \mathrm{A} / \mathrm{cm}^{2}$. This behaviour clearly shows that this inhibitor is able to decrease the corrosion rate of the steel even when it is initially under localized corrosion attack.

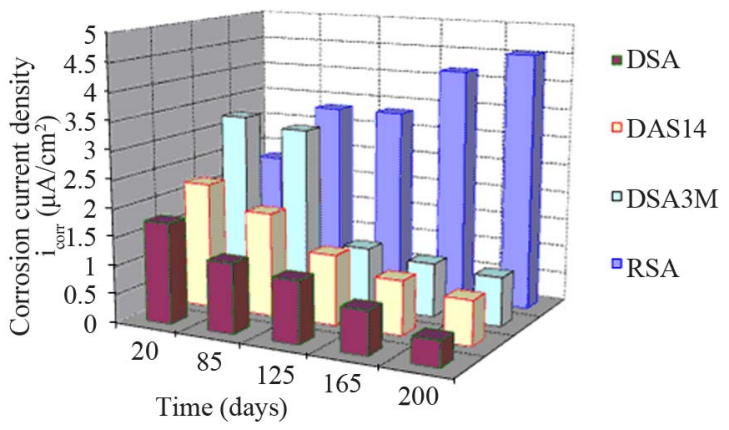

Figure 4. Corrosion current density versus time in cement mortar specimens partially immersed in $3.5 \mathrm{wt} \% \mathrm{NaCl}$ solution.
This points out that the amino alcohol corrosion inhibitor is capable of diffusing through the cement and inhibiting the electrochemical corrosion process by passivation of the anodic and cathodic spots. This is an indication that a barrier layer is built up in the surface of the steel since $i_{\text {corr }}$ values remain constant under the corrosive environment. Despite the significant reduction in the corrosion activity after the addition of the amino alcohol inhibitor, corrosion was not fully eliminated and a moderate level was achieved $\left(0.86 \mu \mathrm{A} / \mathrm{cm}^{2}\right)$.

Results of the linear polarization testing for control specimens and specimens with the corrosion inhibitor as an admixture that were fully immersed in $3.5 \%$ wt. $\mathrm{NaCl}$ solution for 200 days are presented in Figure 5.

Control specimens slightly decrease $i_{\text {corr }}$ values from $0.87 \mu \mathrm{A} / \mathrm{cm}^{2}$ to $0.82 \mu \mathrm{A} / \mathrm{cm}^{2}$ after 200 days of exposure. When using the amino alcohol inhibitor as an admixture, $i_{\text {corr }}$ values are reduced from $0.7782 \mu \mathrm{A} / \mathrm{cm}^{2}$ to 0.6882 $\mu \mathrm{A} / \mathrm{cm}^{2}$. These values are lower than those obtained in the partially immersed specimens due to the saturated environment and to the absence of oxygen that restrains the corrosion process. This difference, after 200 days, is more significant for the control specimens. In fact, $i_{\text {corr }}$ for the control specimens when are partially immersed is approximately $4.5 \mu \mathrm{A} / \mathrm{cm}^{2}$ whereas in the case of full immersion is $0.8 \mu \mathrm{A} / \mathrm{cm}^{2}$. However, the performance of the admixture inhibitor is slightly better under partially immersed solution compared to the performance under saturated environment.

Even under saline saturate environment the action of corrosion amino alcohol inhibitor is slightly better compared to the sample without inhibitor. This can be contributed to the formation of a complex compound (passive film) among the amino alcohol inhibitor, the chloride, the cement materials and the steel. As a result the anodic reaction of iron is in less extend. However, oxygen, a main parameter for the induced corrosion in the system is absent. Thus, the electrochemical corrosion process is not generated.

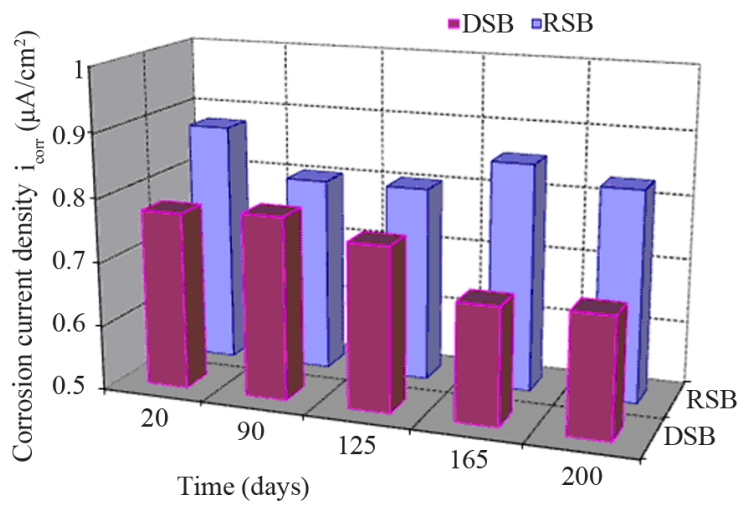

Figure 5. Corrosion current density versus time in cement mortar specimens fully immersed in $3.5 \mathrm{wt} \% \mathrm{NaCl}$ solution. 


\subsection{Weight Loss Measurements of Corroded Steel Rebars}

At the end of the exposure period the cement mortar specimens were carefully broken and the embedded steel bars were recovered. They were visually examined to assess their corrosion state qualitatively and then cleaned according to the ISO/DIS 8407.3 Standard [16] in an aqueous solution of hydrochloric acid containing a proprietary pickling restrainer which served to dissolve the corrosion products and cementitious debris without causing significant attack on the underlying steel.

Mass loss of all specimens that were partially immersed in the corrosive environment was obtained at 135 , 165 and 200 days and the results are shown in Figure 6. Control specimens demonstrate higher mass loss values at all intervals which shows that in the absence of inhibitors the corrosion activity strongly increases with time, leading to higher mass loss. The specimens with addition of the corrosion inhibitor as admixture demonstrate a slightly increase of the mass loss versus time. The mean value of the mass loss at 200 days for the aforementioned specimens is $40 \mathrm{mg}$ which is approximately similar to the value indicated by the specimens where the corrosion inhibitor was sprayed dafter 14 days.

The specimens that were sprayed with the corrosion inhibitor after 3 months of exposure attained a slow increase in the mass loss which is $44 \mathrm{mg}$ after 200 days. These results show the inhibitory effects of amino alcohol corrosion inhibitor in reducing the corrosion even when it is under progress. In the case of the specimens that were fully immersed in $3.5 \mathrm{wt} \% \mathrm{NaCl}$ solution both types of specimens showed similar trend in mass loss values and specifically after 200 days mas loss was 28.6 $\mathrm{mg}$ and $27.5 \mathrm{mg}$ for control specimens and inhibitor amino alcohol admixture respectively as demonstrated in Figure 7.

It should be noted that the difference in the mass loss

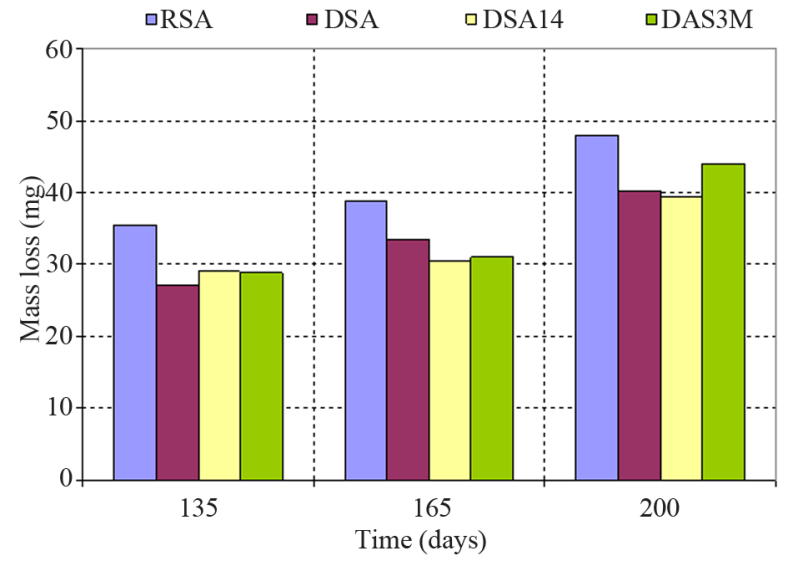

Figure 6. Mass loss of reinforcing steel bars time dependence partially immersed in $3.5 \mathrm{wt} \% \mathrm{NaCl}$ solution.

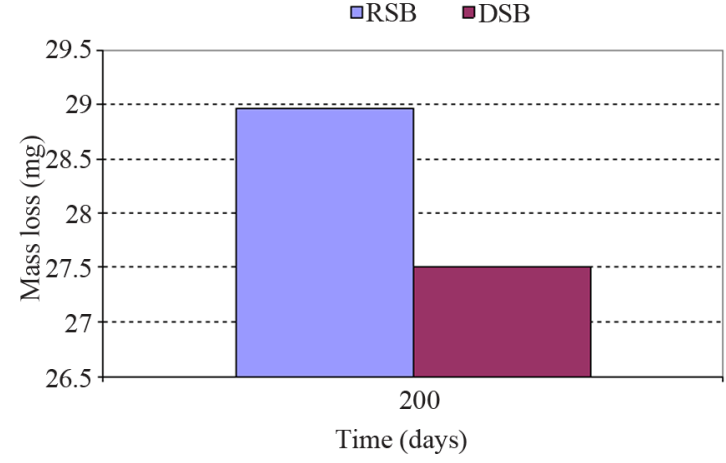

Figure 7. Mass loss of reinforcing steel bars time dependence fully immersed in $3.5 \mathrm{wt} \% \mathrm{NaCl}$ solution.

of the fully immersed specimens in $3.5 \mathrm{wt} \% \mathrm{NaCl}$ solution both in control and in treated with corrosion inhibittor cement mortar specimens is not significantly important. This fact suggests that the absence of oxygen in the pores of cement mortar mass reduces the corrosion rates of steel reinforcements. This behaviour is in disagreement with the half-cell potential results which showed very negative results due to the absent of cathodic reaction. In fact, the specimens with the amino alcohol inhibitor show slightly more efficient in chloride attack than the control specimens. This difference can be explained as a result of inhibition of the anodic reaction on the steel due to the form of passive film by the amino alcohol. This could be an indication that the creation of the passive film could be independent on the presence of oxygen.

Moreover, the mass loss of the control specimens under partial immersed $\mathrm{NaCl}$ solution is dramatically higher compared with the mass loss at saturate $\mathrm{NaCl}$ solution. These results are in line with the results of the linear polarization analysis. In addition the mass loss of admixture inhibitor is also higher under partial immersed $\mathrm{NaCl}$ solution compared with the saturated environment. However, the results of the corrosion rate at linear polarization analysis showed slightly better performance of the admixture inhibitor at partially immersed $\mathrm{NaCl}$ solution.

The absent of oxygen in the saturated environment contribute to the elimination of the cathodic reaction so there is a possibility of a slightly wrong estimation of the corrosion current density.

\section{Conclusions}

The following conclusions can be drawn from this investigation:

1) The amino alcohol types of corrosion inhibitors studied in this work (admixture and sprayed corrosion inhibitor) reduce the corrosion rate of the reinforcing steel when the specimens were partially immersed in a $3.5 \mathrm{wt} \% \mathrm{NaCl}$ solution. In fact, according to the results 
of half-cell potential and linear polarization, admixture type is slightly more efficient in the cement mortar specimens than the surface applied amino alcohols corrosion inhibitors.

2) In cement mortar specimens fully immersed in 3.5 $w t \% \mathrm{NaCl}$ both control and admixture amino alcohol treated specimens demonstrate low corrosion activity because pores of cement mortar are filled with water and oxygen cannot penetrate.

3) There is a decrease of the corrosion activity on steel in the addition of the amino alcohol spaying inhibitor in cement mortar samples even when the cement mortar specimens are initially under localized corrosion attack (partially immersed in a $3.5 \mathrm{wt} \% \mathrm{NaCl}$ ).

From the above, the goal of this paper to test the inhibitory action of the amino alcohol corrosion inhibitor under corrosive environments was achieved.

However, further research needs to be held regarding the mechanism that the amino alcohol corrosion inhibitor acts under the presence of high chloride concentration which diffuses in the cement. Moreover, the characteristic of the passive layer that is created by the inhibitor on the steel surface under different corrosive environment (partially corrosive environment or saturated environment) and under different addition method of the inhibitor (as admixture or sprayed) can be investigated.

\section{REFERENCES}

[1] U. Nürberger, "Korrosionsschutz im Massivbau," Expert Verlag, Böbligen, 1991.

[2] G. Batis and P. Pantazopoulou, "Advantages of the Simoultaneous Use Of Corrosion Inhibitors and Inorganic Coating," Cement and Concrete Technology in the 2000s Second International Symposium, Instabul, 6-10 September 2000, pp. 474-483.

[3] M. J. Gaidis, "Chemistry of Corrosion Inhibitors," Cement \& Concrete Composites, Vol. 26, No. 3, 2004, pp. 181-189. doi:10.1016/S0958-9465(03)00037-4

[4] M. Pourbaix, "Atlas of Electrochemical Equilibria in Aqueous Solutions," Pergamon Press, Oxford, 1966.

[5] J. P. Broomfield, "Assessing Corrosion Damage on Reinforced Concrete Structures," Proceedings of the International Conference Corrosion and Corrosion of Steel in Concrete, Sheffield, 24-28 July 1994, pp. 1-25.

[6] C. M. Hansson, L. Mammoliti and B. B. Hope, "Corrosion Inhibitors in Concrete-Part I: The Principles," $\mathrm{Ce}$ ment and Concrete Research, Vol. 28, No. 12, 1998, pp. 1775-1781. doi:10.1016/S0008-8846(98)00142-2

[7] L. Fedrizzi, F. Azzolini and P. L. Bonora, "The Use of Migrating Corrosion Inhibitors to Repair Motorways Concrete Structures Contaminated by Chlorides," Cement and Concrete Research Vol. 35, No. 3, 2005, pp. 551-561. doi:10.1016/j.cemconres.2004.05.018

[8] M. Ormellese, M. Berra, F. Bolzoni and T. Pastore, "Corrosion Inhibitors for Chlorides Induced Corrosion in Re- inforced Concrete Structures," Cement and Concrete Research, Vol. 36, No. 3, 2006, pp. 536-547.

doi:10.1016/j.cemconres.2005.11.007

[9] M. Duprat, N. Bui and F. Dabosi, "Corrosion-NACE," Vol. 35, No. 9, 1979, p. 392. doi:10.5006/0010-9312-35.9.392

[10] M. Duprat and F. Dabosi, "Corrosion-NACE," Vol. 37, No. 2, 1981, p. 89. doi:10.5006/1.3593851

[11] U. Maeder, "A New Class of Corrosion Inhibitors for Reinforced Concrete," Proceedings in the 9th Asian-Pacific Corrosion Control Conference, "Corrosion Prevention for Industrial Safety and Environmental Control", Taiwan, 1995, pp. 825-830.

[12] A. Welle, J. Liao, K. Kaiser, M. Grunze, U. Mader and N. Blank, "Interactions of N,N-Dimethylaminoethanol with Steel Surfaces in Alkaline and Chloride Containing Solutions," Applied Surface Science, Vol. 119, No. 3-4, 1997, pp. 185-190. doi:10.1016/S0169-4332(97)00216-X

[13] I. Martínez, C. Andrade, N. Rebolledo, L. Luo and G. De Schutter, "Corrosion-Inhibitor Efficiency Control: Comparison by Means of Different Portable Corrosion Rate Meters," Corrosion: The Journal of Science and Engineering, Vol. 66, No. 2, 2010, pp. 026001-026001-12. doi:10.5006/1.3319663

[14] Hellenic Organization for Standardization ELOT 452, "Determination of Total $\mathrm{Hg}$ Content to Water with Atomic Absorption Spectroscopy," Athens, 1983.

[15] Hellenic Organization for Standardization ELOT 1421-3, "Steel for the Reinforcement of Concrete-Weldable Reinforcing Steel-Part 3: Technical Class B500C," Athens, 2005.

[16] ISO/DIS 8407.3, "Procedures for removal of corrosion products from corrosion test specimen," Genève, Switzerland, 1986.

[17] A. Routoulas, P. Pantazopoulou and G. Batis, "Evaluation of Parameters Influencing Reinforcement Corrosion by Means of a Strain Gauge Technique," Anti-Corrosion Methods and Materials, Vol. 50, No. 4, 2003, pp. 271279. doi:10.1108/00035590310482505

[18] F. Wombacher, U. Maeder and B. Marazzani, "Aminoalcohol based mixed corrosion inhibitors," Cement \& Concrete Composites, Vol. 26, No. 3, 2004, pp. 209-216. doi:10.1016/S0958-9465(03)00040-4

[19] A. S. Abdulrahman, I. Mohammad and S. H. Mohammad, "Corrosion Inhibitors for Steel Reinforcement in Concrete: A Review," Scientific Research and Essays, Vol. 6, No. 20, 2011, pp. 4152-4162.

[20] ASTM C 876-91, "Standard Test Method for Half-Cell Potential of Reinforcing Steel in Concrete," Annual Book of ASTM Standards. ASTM International, West Conshohocken, 1991.

[21] European Concerted Action COST 509, "Corrosion and Protection of Metals in Contact with Concrete: Part 2. Monitoring," Final Report, European Commission, Brussel, 1997, p. 73.

[22] J. P. Broomfield, "Condition Evaluation, Corrosion of Steel in Concrete,” E\&FN SPON, London, 1997. doi: $10.4324 / 9780203414606$ 
[23] H. E. Jamil, M. F. Montemor, R. Boulif, A. Shriri and M. G. S. Ferreira, "An Electochemica and Analytical Approach to the Inhibition Mechanism of an Amino-Alcohol-Based Corrosion Inhibitor for Reinforced Concrete," Electrochemica Acta, Vol. 48, No. 23, 2003, pp. 35093518. doi:10.1016/S0013-4686(03)00472-9

[24] E. Jamil, A. Shriri, R. Boulif, A. C. Bastos, M. F. Montemor and M. G. S. Ferreira, "Electrochemical Behaviour of Amino Alchohol Based Inhibitors Used to Control Corrosion of Reinforcing Steel," Electrochemica Acta, Vol. 49, No. 17-18, 2004, pp. 2753-2760. doi:10.1016/j.electacta.2004.01.041

[25] H. E. Jamil, A. Shriri, R. Boulif, M. F. Montemor and M. G. S. Ferreira, "Corrosion Behaviour of Reinforcing Steel Exposed to an Amino Alcohol Based Corrosion Inhibitor," Cement and Concrete Composites, Vol. 27, No. 6, 2005, pp. 671-678.

[26] M. Sánchez and C. Alonso, "Accelerated Transport of Corrosion Inhibitors as Complementary Methodology for Electrochemical Chlorides Extraction Method," 2nd International Conference on Concrete Repair, Rehabilita- tion and Retrofitting, Cape Town, 24-26 November 2008, pp. 289-290.

[27] J. Kubo, S. Sawada, C. L. Page and M. M. Page, "Electrochemical Inhibitor Injection for Control of Reinforcement Corrosion in Carbonated Concrete," Materials and Corrosion, Vol. 59, No. 2, 2008, pp. 107-114. doi:10.1002/maco.200804161

[28] H. Zheng, W. Li, F. Ma and Q. Kong, "The Effect of a Surface-Applied Corrosion Inhibitor on the Durability of Concrete," Construction and Building Materials, Vol. 37, 2012, pp. 36-40. doi:10.1016/j.conbuildmat.2012.07.007

[29] M. Ormellese, F. Bolzoni, L. Lazzari and P. Pedeferri, "Effect of Corrosion Inhibitors on the Initiation of Chloride-Induced Corrosion on Reinforced Concrete Structures," Materials and Corrosion, Vol. 59, No. 2, 2008, pp. 98-106. doi:10.1002/maco.200804155

[30] T. A. Nguyen and X. Shi, "A Mechanistic Study of Corrosion Inhibiting Admixtures," Anti-Corrosion Methods and Materials, Vol. 56, No. 1, 2009, pp. 3-12. doi:10.1108/00035590910923400 